Corrigendum

\title{
Corrigendum to "Analysis and Determination of Trace Metals (Nickel, Cadmium, Chromium, and Lead) in Tissues of Pampus argenteus and Platycephalus indicus in the Hara Reserve, Iran"
}

\begin{abstract}
Journal of Toxicology
Received 19 November 2020; Accepted 19 November 2020; Published 21 December 2020

Copyright (C) 2020 Journal of Toxicology. This is an open access article distributed under the Creative Commons Attribution License, which permits unrestricted use, distribution, and reproduction in any medium, provided the original work is properly cited.
\end{abstract}

The article titled "Analysis and Determination of Trace Metals (Nickel, Cadmium, Chromium, and Lead) in Tissues of Pampus argenteus and Platycephalus indicus in the Hara Reserve, Iran" [1] was found to contain nearly 1000 words taken from the authors' published work [2], which was not cited. The articles measured the same elements in two different species of fish collected from the same study site. The article is as follows:

Sahar Mohammadnabizadeh, Alireza Pourkhabbaz, Reza Afshari, and Mohsen Nowrouzi, "Concentrations of Cd, Ni, Pb, and $\mathrm{Cr}$ in the two edible fish species Liza klunzingeri and Sillago sihama collected from Hara biosphere in Iran," Toxicological \& Environmental Chemistry, vol. 94, no. 6, pp. 1144-1151, 2012, doi: 10.1080/02772248.2012.693494.
The authors do not agree to the publication of this corrigendum.

\section{References}

[1] S. Mohammadnabizadeh, A. Pourkhabbaz, and R. Afshari, "Analysis and determination of trace metals (Nickel, Cadmium, Chromium, and Lead) in tissues of Pampus argenteus and Platycephalus indicus in the Hara Reserve, Iran," Journal of Toxicology, vol. 2014, Article ID 576496, 6 pages, 2014.

[2] S. Mohammadnabizadeh, A. Pourkhabbaz, R. Afshari, and M. Nowrouzi, "Concentrations of $\mathrm{Cd}, \mathrm{Ni}, \mathrm{Pb}$, and $\mathrm{Cr}$ in the two edible fish species Liza klunzingeri and Sillago sihama collected from Hara biosphere in Iran," Toxicological \& Environmental Chemistry, vol. 94, no. 6, pp. 1144-1151, 2012. 